\title{
UN CAZ DEOSEBIT DE TUBERCULOZĂ LARINGIANĂ
}

\section{Bidilean Nicolae', Bidilean Maria-Cristina², Bidilean Sînziana-Alexandra³, Pallai Laszlo ${ }^{4}$}

${ }^{I}$ medic primar ORL Spitalul Județean Satu Mare, ${ }^{2}$ studentă an VI UMF Iuliu Hațieganu Cluj-Napoca, ${ }^{3}$ studentă an III UMF Iuliu Hațieganu Cluj-Napoca, ${ }^{4}$ medic specialist pneumoftiziolog Spitalul Județean Satu Mare

\section{Title: One uncommon larynx tuberculosis case}

\section{Abstract}

The authors prezent a larynx tuberculosis case, with a dysphonia onset. The initial endoscopic aspect suggested ulcero-edematous chronical laryngitis. The diagnosis of pulmonary tuberculosis with secondary larynx tuberculosis was confirmed by subsequent investigations. The specific treatment against tuberculosis soothed the pulmonary lesions and healed the lesions of the larynx. We observed endoscopical the evolution of the larynx tuberculosis at the begining, during the treatment, and at the end of it. endoscopy.

Key words: dysphonia, ulcero-edematous chronical laryngitis, secondary tuberculosis, laryngial

\section{Rezumat}

Autorii prezinta un caz de tuberculoză laringiană a cărui simptom de debut a fost disfonia. Aspectul endoscopic inițial a sugerat o laringită cronică ulcero-edematoasă. Investigațiile ulterioare au confirmat diagnosticul de tuberculoză pulmonară cu laringită tuberculoasă secundară. Tratamentul specific antituberculos a dus la ameliorarea netă a leziunilor pulmonare şi vindecarea leziunilor laringiene. A fost urmarită evoluția aspectului endoscopic laringian la începutul, mijlocul şi sfârşitul tratamentului antituberculos.

Cuvinte cheie: disfonie, laringita cronică ulcero-edematoasă, tuberculoză secundară, endoscopie laringiană.

\section{Introducere}

Prezentăm cazul unui pacient care se prezintă la cabinetul ORL cu simptomatologia unei afecțiuni laringiene care, fiind investigat complex, s-a dovedit a fi o tuberculoză pulmonară cu determinări secundare laringiene.

\section{Material şi metode}

Pacientului i s-a efectuat anamneza, examenul obiectiv pe sisteme și aparate, examen local ORL, endoscopie laringiană cu aparatul Optomic, sursă de lumină rece, tija endoscopică de 70 grade. La Spitalul de Pneumoftiziologie Satu Mare s-au efectuat anamneza, examenul obiectiv, radiografii toracice față, profil, tomografii toracice, examen bacteriologic al sputei direct pentru BK și cultura. 
Motivele prezentării pacientului la medic au fost: disfonie persistentă de 4 luni, dureri la deglutiție, tuse cu expectorație muco-purulentă, scădere în greutate $10 \mathrm{~kg}$, apetit capricios, dispnee de efort. Din antecedentele eredocolaterale menționăm diabetul zaharat de tip II de care suferă mama pacientului. Din antecedentele personale, nu găsim date care să ne orienteze spre diagnostic, cu excepția unei perioade de 4 ani în care pacientul a lucrat ca miner în subteran. Pacientul este fumător, 30-40 țigări pe zi, consumul de alcool este ocazional, se alimentează corespunzător, iar membrii familiei sunt clinic sănătoşi.

Istoricul bolii: pacientul afirmă că în urmă cu 4 luni, în urma unei "răceli” a rămas cu o disfonie, tuse seacă inițial, ulterior productivă. $\mathrm{Nu}$ s-a prezentat la medic, decât cu 2 săptămâni înaintea consultului ORL. În evoluție, disfonia se accentuează, apare disfagia, pacientul prezintă slăbire în greutate, apetit capricios, dispnee de efort.

Examenul clinic ne înfățişează un pacient astenic, cu facies emaciat, palid, disfonic, subfebril. Examenul ORL nu relevă date patologice rinosinusale, otice, arată în schimb o uşoară congestie a istmului orofaringian, sialoree, laringoscopia indirectă evidențiază o tumefiere masivă alb-gălbuie a epiglotei, plicilor ariepiglotice, a mucoasei aritenoidiene, a corzilor vocale, stază salivară în ambele sinusuri piriforme. Mobilitatea aritenoizilor în fonație şi respirație este păstrată. $\mathrm{Nu}$ am decelat noduli la palparea regiunii cervicale. Endoscopia laringiană efectuată cu laringoscopul de 70 de grade confirmă aspectul descris la laringoscopia indirectă, la nivelul plicii ariepiglotice drepte evidențiind leziuni ulcerative pe fondul alb-gălbui al mucoasei, noduli gălbui pe toata mucoasa laringiană.

În această etapă am suspicionat o afecțiune cronică laringiană şi anume o laringită specifică şi am cerut un examen ftiziologic în acest sens.

Examenul ftiziologic efectuat la Spitalul de Pneumoftiziologie Satu Mare a arătat prin radiografia pulmonară opacități nodulo-infiltrative care ocupă 3/4 superioare bilateral, mai mari superior (fig. 2). La examenul tomografic pulmonar la 5-7-9 cm, pe imaginile de 7 şi $9 \mathrm{~cm}$, superior drept se conturează mai multe imagini inelare de diferite mărimi, în stânga una de $4 \times 6 \mathrm{~cm}$, şi mai multe mici ulceraţii (fig. 3). Examenul sputei pentru BK: 3 probe sunt intens pozitive. Pacientul este diagnosticat cu tuberculoză pulmonară, forma cazeoasă, extinsă policavitar, bilateral, laringită tbc, BK pozitiv.

Pacientul a fost internat în Spitalul de Pneumoftiziologie şi a urmat un tratament specific timp de 3 luni.

Am urmărit clinic şi endoscopic leziunile laringiene şi am constatat după 2 luni o reducere însemnată a tumefierii mucoasei epiglotei, a aritenoizilor, dispariția ulcerațiilor de pe coroana laringiană (fig. 4). La 3 luni de tratament aspectul endoscopic al laringelui este normal, disfonia a dispărut, disfagia a dispărut, pacientul a crescut în greutate, starea generală este net ameliorată (fig. $5,6,7)$.

\section{Considerații asupra cazului}

Acest caz, prin complexitatea simptomatologiei (respiratorie, faringo-laringiană) a pus probleme în primul rând de diagnostic şi în al doilea rând de diagnostic diferențial cu afecțiuni asemănătoare clinic şi redutabile ca evoluție şi prognostic.

Diagnosticul diferențial pe baza anamnezei şi examenului obiectiv ORL şi endoscopic se impune cu celelalte laringite cronice specifice: sifilitică, scleromul laringian, sarcoidoza cu afectare laringiană, actinomicoza laringiană, micozele laringiene, manifestările laringiene din dermatoze, amiloidoza laringiană. Diferențierea față de aceste afecțiuni se face în context clinic, epidemiologic, examinări de laborator (teste serologice VDRL, TPHA, examene bacteriologice din spută, examene micologice şi culturi pe mediul Sabouraud, reacția Bordet-Gengou pentru scleromul laringian), biopsie cu colorație roşu de Congo pentru amiloidoză, biopsie cu examen histopatologic în caz de incertitudine a diagnosticului. 
Laringitele cronice nespecifice: catarală cronică, pseudomixomatoasă, hipertrofică roşie, hipertrofică albă, necesită diferențiere prin examen bacteriologic, examen micologic al secrețiilor, fibroscopie, laringoscopie suspendată cu biopsie şi examen histopatologic, explorări imunohistochimice.

Tumorile benigne şi maligne laringiene necesită pentru diagnostic examinările menționate anterior, iar hotărâtoare este biopsia laringiană recoltată în anestezie generală prin laringoscopie suspendată şi examen histopatologic.

O parte din afecțiunile amintite, au fost diferențiate prin examenul clinic laringoscopic şi de laborator, iar evoluția favorabilă sub tratamentul specific antituberculos nu a impus efectuarea biopsiei laringiene şi a examenului histopatologic. Vindecarea leziunilor laringiene în urma tratamentului tuberculostatic a confirmat diagnosticul de laringită tbc secundară.

\section{Concluzii}

Am considerat necesară prezentarea acestui caz din următoarele motive: dificultatea diagnosticului pozitiv, multitudinea de diagnostice diferențiale care intrau în discuție și care trebuiau excluse, lucru care implică multă muncă și timp, aportul însemnat al endoscopiei în evidențierea leziunilor laringiene, colaborarea deosebită cu specialitatea de Pneumoftiziologie în diagnosticul și rezolvarea terapeutică a cazului.

\section{Referințe}

1. Bacalbaşa, A, Drăgulescu, AC, Chitac, M. Diagnostic pozitiv şi diferențial în ORL, Editura MedicArt, Bucuresti, 2004,177-199

2. Van Cauwenberge, P. Oto-Rhino-Laryngologie, Omega Editions Gand, 1990,312-318

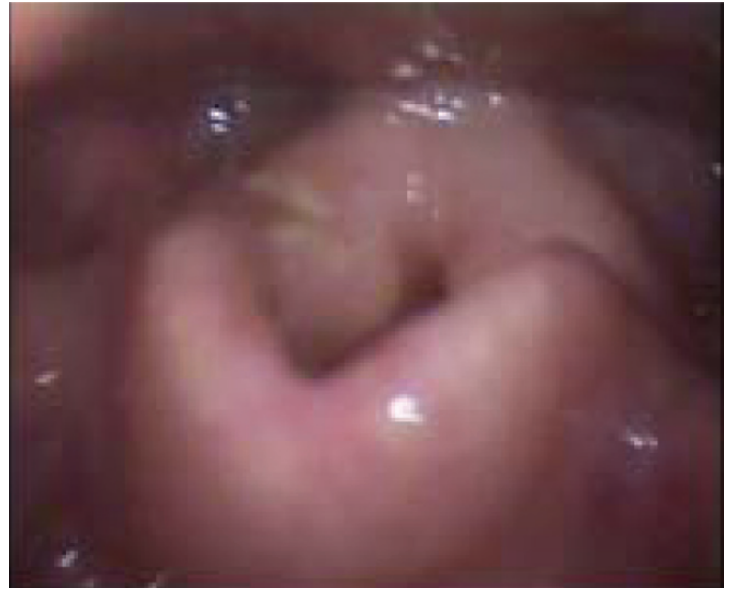

Fig. 1 Aspectul leziunilor laringiene la debut (arhiva proprie)

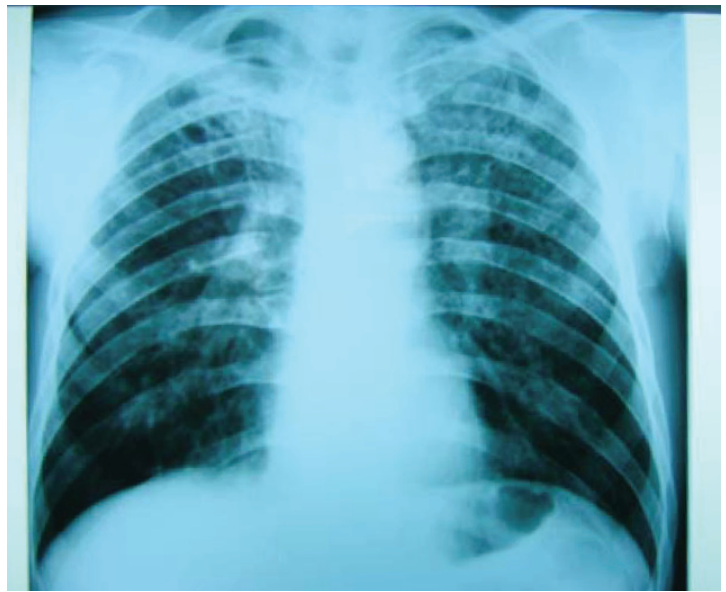

Fig.2 Radiografia pulmonară la internarea cazului 


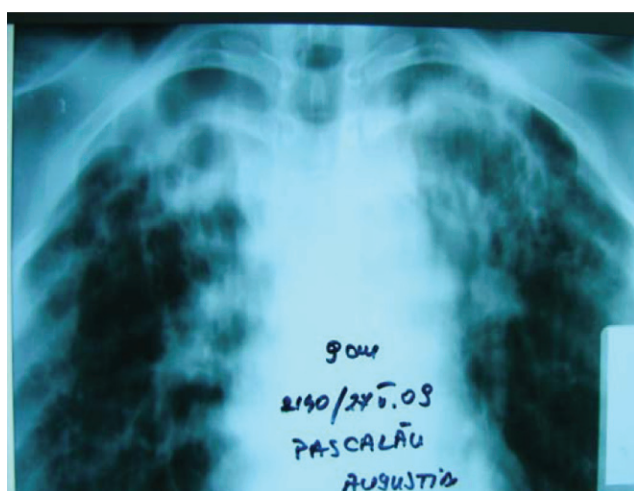

Fig.3 Tomografia pulmonară la internare

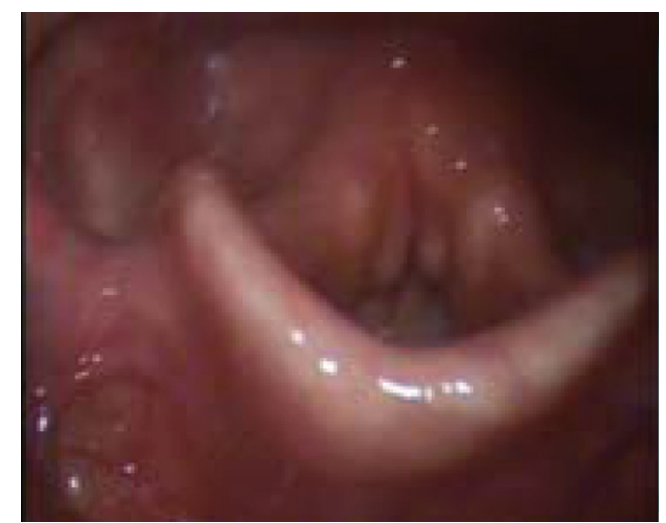

Fig. 5 Aspectul laringelui după 3 luni de tratament (arhiva proprie)

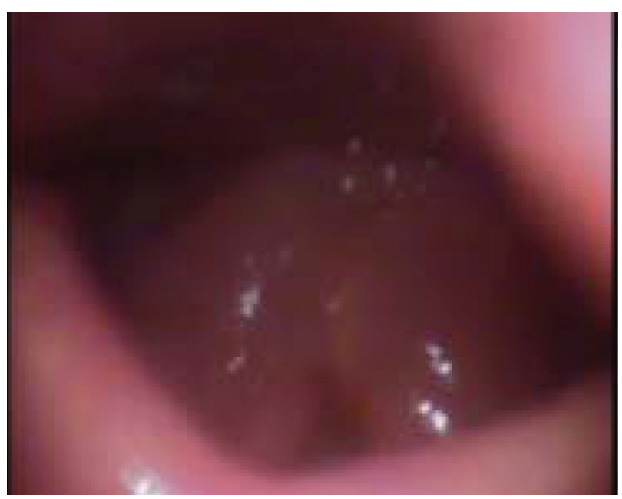

Fig.4 Aspectul laringelui după 2 luni de tratament (arhiva proprie)

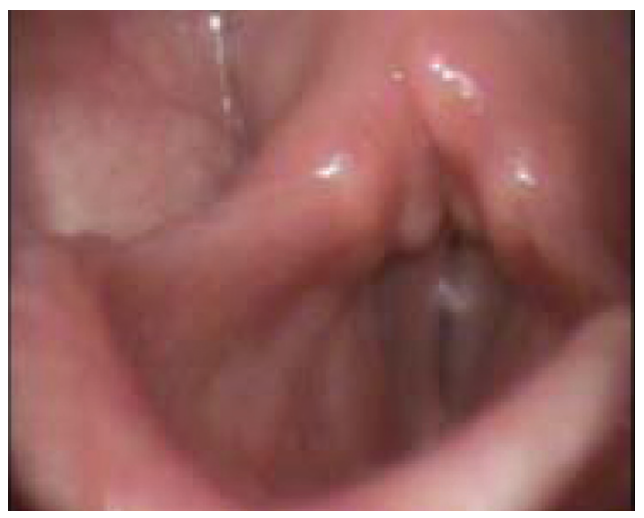

Fig.6 Aspectul laringelui după 3 luni de tratament (arhiva proprie)

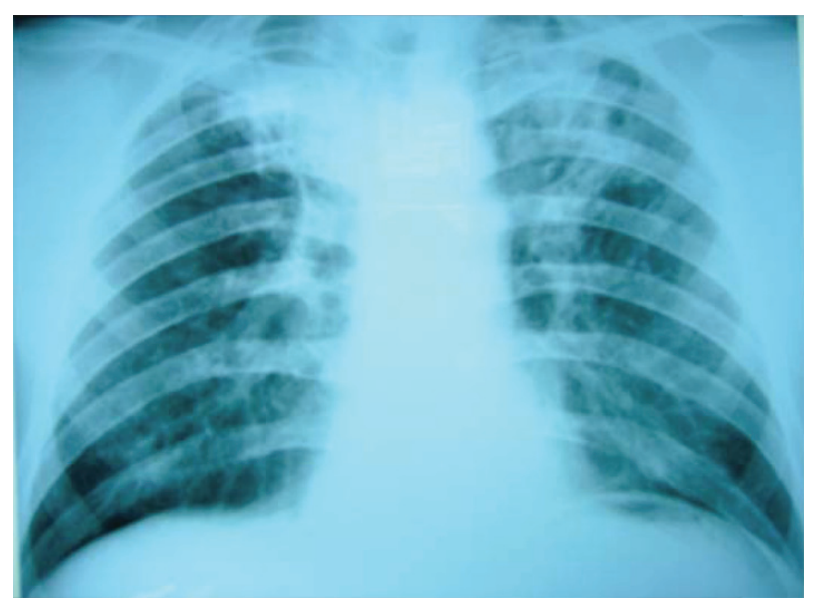

Fig.7 Radiografia pulmonară dupa 3 luni de tratament (arhiva Spitalului de Pneumoftziologie) 